\title{
A Short Review on REE Recovery from Ion-Ad- sorption Clays
}

\author{
Yaraghi A, Ariffin KS* and Baharun N \\ School of Materials and Minerals Resources Engineering, Nibong Tebal, Penang, Malaysia
}

ISSN: 2578-0255

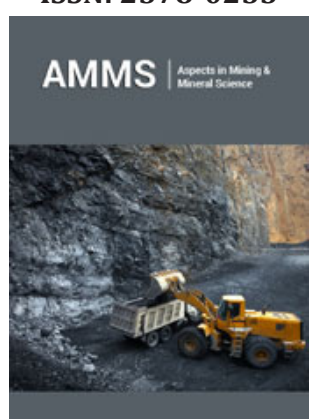

*Corresponding author: Ariffin KS School of Materials and Minerals Resources Engineering, Universiti Sains Malaysia, Nibong Tebal, Penang, Malaysia

Submission: 制 May 13, 2019

Published: 監May 28, 2019

Volume 2 - Issue 5

How to cite this article: Yaraghi A, Ariffin K, Baharun N. A Short Review on REE Recovery from Ion-Adsorption Clays. Aspects Min Miner Sci.2(5). AMMS.000550.2019.

DOI: 10.31031/AMMS.2019.02.000550.

Copyright@ Ariffin KS, This article is distributed under the terms of the Creative Commons Attribution 4.0 International License, which permits unrestricted use and redistribution provided that the original author and source are credited.

\begin{abstract}
In temperature and tropical regions, Rare Earth Elements (REE)s-bearing minerals abundant in particular igneous rocks normally decompose to REE3 + throughout chemical weathering then absorbs on the surface of weathered rock forming minerals and form ion-adsorption clay REE deposits. Due to obtainability of REEs in ion-exchangeable phases in such deposits, simple diluted electrolyte solution such as Ammonium Sulphate can extract significant amount of REEs at ambient temperature. Through different types of leaching methods can be utilized which are heap, tank/pool, and in-situ leaching methods, in-situ leach mining is the dominating technology now cause of more efficiency and less environmental impacts. Later on, more pured REE solutions can be achieved by using advanced techniques such as solvent extraction.
\end{abstract}

\section{Introduction}

Rare Earth Elements (REEs: La-Lu Plus Y and Sc [1]) are known to be enriched in the melt mantle during magmatic differentiation. They can also be enriched in the granitoids through the accumulation of REE-bearing minerals such as apatite, allanite, monazite, titanite and xenotime, since they tend to remain in the melt until the late stages of magmatic differentiation [2]. Rare earth deposits are formed by different geological processes in deep-seated intrusive environment, magmatic-hydrothermal environment, and surface weathering environment. REE resources can be divided into two categories: primary deposits associated with igneous and hydrothermal processes and secondary deposits concentrated by sedimentary processes and weathering. Within these two groups, REE deposits can be further subdivided depending on their genetic, mineralogy and form of occurrence [3]. Two significant types of secondary deposits are the placer and ion-adsorption clays deposits. REEs ion-adsorption type deposits are formed by weathering of igneous rocks (typically granites) that contain particular REEbearing minerals. Due to surface weathering, REE minerals are decomposed, and ionized REEs $\left(\mathrm{REE}^{3+}\right)$ are absorbed on clay minerals (normally kaolin and smectite groups). Ion-adsorption ores generally contain higher amount of HREEs and lower amounts of Th and $U$ than other REE ores [4].

Promoting of intensive chemical weathering and breakdown of REE-bearing minerals by temperate and tropical climates (based on Koppen-Geiger climate classification [5]) suggest that those regions -with igneous bedrock- are potential zones for ion-adsorption clay REE resources. Southern China has the most developed ion-adsorption type deposits currently [6], however, several projects have been also known in the countries outside China in the recent years [7] such as: The Tantalus REE project in northern Madagascar, The Malawi REE project, The Serra Verde REE project in Brazil [8] as well as some other projects in Myanmar, Vietnam [9] and western Thailand [10].

\section{Processing}

Mineralogy is a key variable in determining the ease or difficulty, the cost of processing and extraction of REEs. Primary, hard rock deposits with the most abundant REE minerals such as bastnäsite, monazite, xenotime, loparite, parasite, and perhaps apatite is more likely to be economical compared with those deposits with eudialyte, allanite, or zircon $[11,12]$. Cause the latter group are more refractory and economic processing of REE from these minerals is not currently possible. In ion-adsorption ores, REEs are mostly present in ion-exchangeable phase of weathered granites, therefor, blasting, crushing, grinding, or mineral processing are 
not needed. REEs are easily extracted by ion exchange using diluted electrolyte solutions such as ammonium sulfate solution at ambient temperature [13-17].

There are different types of leaching methods have been utilized to extract REEs from ion-adsorption clays, such as heap, tank/pool, and in-situ leaching methods [18]. Previously, heap leaching was a commonly operated method which involves excavating minerals, placing them in a mound, and spraying them with solutions [17]. Tank/pool leaching involves placing the minerals into a tank/pool and immersed with solutions [18]. In-situ leach mining is now the dominating technology, given that there is less topsoil removed, the process can be performed on site, and the environmental impacts are reduced $[19,20]$.

The schematic monovalent salt leaching extraction of $\mathrm{REE}^{3+}$ (Figure 1) suggested by recent studies [21] is:

$$
\begin{aligned}
& {\left[\mathrm{Al}_{2} \mathrm{Si}_{2} \mathrm{O}_{5}(\mathrm{OH})_{4}\right]_{\mathrm{m}} \cdot \mathrm{nREE}_{(\mathrm{s})}{ }^{3+}+3 \mathrm{nN}_{\mathrm{H} 4}{ }^{+}(\mathrm{aq}) \leftrightarrow\left[\mathrm{Al}_{2} \mathrm{Si}_{2} \mathrm{O}_{5}(\mathrm{OH})_{4}\right]} \\
& \mathrm{m}^{\cdot} \cdot\left(\mathrm{NH}_{4}^{+}\right)_{3 \mathrm{n}(\mathrm{s})}^{3+}+\mathrm{nREE}_{(\mathrm{aq})}{ }^{3+}
\end{aligned}
$$

In most cases, the rare earth leach liquor contains a significant amount of some impurities such as $\left(\mathrm{NH}_{4}\right)_{2} \mathrm{SO}_{4}, \mathrm{Al}^{3+}, \mathrm{Fe}^{3+}$ and $\mathrm{Ca}^{2+}$, accompanied by a small amount of $\mathrm{Fe}^{2+}, \mathrm{Pb}^{2+}$ and $\mathrm{Mn}^{2+}$ [22]. The traditional process of extracting rare earth from such leach liquor is usually treated with chemical precipitation with oxalic acid or ammonium carbonate as precipitant, forming rare earth oxalate or carbonate, followed by washing and filtering and calcining into rare earth oxides $[23,24]$. However, the rare earth oxides need to be dissolved with hydrochloric acid before being separated by solvent extraction or used as materials for many rare earth users [25]. Although, they have been applied to industry practice, these precipitation technologies are complicated, time-and reagentconsuming, and the serious disadvantage is that these impurity ions cannot be removed, and the product purity is low, in addition, the rare earth yield is also low [26]. Recently, efficient nonprecipitation techniques such as solvent extraction, ion exchange, and liquid membranes has been developed and applied in some mining sites [27].

\section{Conclusion}

Simple divalent electrolyte solution such as $\left(\mathrm{NH}_{4}\right)_{2} \mathrm{SO}_{4}$ are capable to extract the significant amounts of REEs absorbed on clay minerals such as kaolinite, halloysite and montmorillonite at room temperature cause of REEs accumulation in ion-exchangeable phase of ion-adsorption REE deposits. The leachate was then precipitate using oxalic acid or ammonium carbonate followed by a roasting stage. Obtained mixed REEs oxide contains a significant amount of impurities which purify by means of hydrochloric acid dissolution technique before applying further fine separation techniques. New researches are investigating on non-precipitation methods such as solvent extraction, ion-exchange and liquid membranes due to low product purity of precipitation methods.

Research Grant: USM 304.P. Bahan.6050350

\section{References}

1. Meija J, Coplen TB, Berglund M, Brand WA, Bièvre PD, et al. (2016) Atomic weights of the elements 2013 (IUPAC Technical Report). Pure and Applied Chemistry 88: 265-291.

2. Castor SB, Hedrick JB (2006) Rare earth elements. In: Miner I (Ed.), ( $7^{\text {th }}$ edn), Society for Mining, Metallurgy, and Exploration, Inc, Littleton, USA, pp. 769-792.

3. Lusty P, Walters A (2010) Rare earth elements.

4. Hoshino M, Sanematsu K, Watanabe Y (2016) REE mineralogy and resources. In: Bunzli JC, Pecharsky VK (Eds.), Handbook on the Physics and Chemistry of Rare Earths, Elsevier, Netherlands, 49: 129-291.

5. Peel MC, Finlayson BL, McMahon TA (2006) Updated world map of the Koppen-Geiger climate classification. Meteorol Zeitschrift 15: 259-263.

6. Xie Y, Hou Z, Goldfarb RJ, Guo X, Wang L (2016) Rare Earth Element Deposits in China. Rev Econ Geol-Rare Earth Crit Elem Ore Depos, pp. 115-136.

7. Sanematsu K, Watanabe Y (2016) Characteristics and genesis of ion adsorption-type rare earth element deposits, Rev Econ Geol 18: 55-79.

8. Coutinho F (2015) Serra verde project.

9. Mentani T (2012) So-called ion-adsorption type REE deposits found in weathered crust of ilmenite-series granite in Northern Vietnam, University of Tokyo, Japan.

10. Sanematsu K, Kon Y, Imai A, Watanabe K, Watanabe Y (2013) Geochemical and mineralogical characteristics of ion-adsorption type REE mineralization in Phuket, Thailand. Mineralium Deposita 48(4): 437-451.

11. Chakhmouradian AR, Wall F (2012) Rare earth elements: minerals, mines, magnets (and more). Elements 8(5): 333-340.

12. Mariano A (2012) Rare earth mining and exploration in North America. Elements 8(5): 369-376.

13. Wu C, Yuan Z, Bai G (1996) Rare earth deposits in China, Rare Earth Miner. Chem Orig.

14. Jun T, Jingqun Y, Ruan C, Guohua R, Mintao J (2010) Kinetics on leaching rare earth from the weathered crust elution-deposited rare earth ores with ammonium sulfate solution. Hydrometallurgy. 101(3-4): 166-170.

15. He Z, Zhang Z, Chi R, Xu Z, Yu J, et al. (2017) Leaching hydrodynamics of weathered elution-deposited rare earth ore with ammonium salts solution. Journal of Rare Earths 35(8): 824-830.

16. Moldoveanu GA, Papangelakis VG (2012) Recovery of rare earth elements adsorbed on clay minerals: I. desorption mechanism. Hydrometallurgy 117-118: 71-78

17. Papangelakis VG, Moldoveanu G (2014) Recovery of Rare Earth Elements from Clay Minerals. $1^{\text {st }}$ European Rare Earth Resources Conference, pp. 191-202.

18. Yang XJ, Lin A, Li XL, Wu Y, Zhou W (2013) China's ion-adsorption rare earth resources, mining consequences and preservation, Environmental Development 8: 131-136.

19. Chi R, Tian J, Li Z, Peng C, Wu Y, et al. (2005) Existing state and partitioning of rare earth on weathered ores. J Rare Earths 23(6): 756-759.

20. Schüler D, Buchert M, Liu R, Dittrich S, Merz C (2011) Study on rare earths and their recycling. 49: 30-40.

21. Chi R, Tian J (2008) Weathered crust elution- deposited rare earth ores. Nova Science Publishers Inc, USA.

22. Bazin C, El-Ouassiti K, Ouellet V (2007) Sequential leaching for the recovery of alumina from a Canadian clay. Hydrometallurgy 88(1-4): 196-201. 
23. Chi R, Zhou Z, Xu Z, Hu Y, Zhu G (2003) Solution-chemistry analysis of ammonium bicarbonate consumption in rare-earth-element precipitation. Metallurgical and Materials Transactions B 34(5): 611617.

24. Chi R, Xu Z (1999) A solution chemistry approach to the study of rare earth element precipitation by oxalic acid. Metallurgical and Materials Transactions B 30(2): 189-195.
25. Huang XW, Long ZQ, Li HW, Ying WJ, Zhang GC, et al. (2005) Development of rare earth hydrometallurgy technology in China. Journal of Rare Earths 23(1): 1-4.

26. Li D (1995) Chemical engineering problems in hydrometallurgical industry of rare earths. Prog Chem 3.

27.Zhongmao G (2003) State of the art and recent progress of liquid membrane separation processes. Chinese Me 214-223.

For possible submissions Click below: 